Discourse and Communication for Sustainable Education, vol. 7, no. 2, pp. 5-16, 2016

\title{
Is Higher Education Economically Unsustainable? An Exploration of Factors that Undermine Sustainability Assessments of Higher Education
}

\author{
Antonios Maragakis \\ Delft University of Technology, the Netherlands \\ Andy van den Dobbelsteen \\ Delft University of Technology, the Netherlands \\ Alexandros Maragakis \\ Eastern Michigan University, the United States
}

\begin{abstract}
As students continue to review the sustainability of higher education institutions, there is a growing need to understand the economic returns of degrees as a function of a sustainable institution. This paper reviews a range of international research to summarize the economic drivers of higher education attainment. Although the cost inputs to higher education are fairly well understood, the economic return of a degree is not. Students misperception of economic returns coupled with a dynamic definition of employability create the framework for unsustainable debt loads for graduates. This paper proposes three metrics that can be used to assess the economic sustainability of students graduating higher education that can be used to supplement the broader definition of sustainability within higher education.
\end{abstract}

Keywords: sustainable development, higher education, economic return, sustainable education, sustainable assessment

Is the discussion surrounding sustainability within higher education missing a key parameter?

The general topic of sustainability assessment has been exhaustively studied, perhaps better studied than sustainability itself (Kates et al., 2001). With relation to higher education numerous scholars (e.g. Ryan, Tilbury, Corcoran, Abe \& Nomura, 2010; Glasser, 2009; Patrick, Murray \& Bowles, 2008; Perna, Carriere, Chang, 2006, Salite, 2008) have investigated and analysed the various assessment systems and inventories of university initiatives currently available. Along with individual institution's efforts, there is a growing number of external certifications gaining popularity, such as the Sustainability Tracking, Assessment \& Rating System (STARS) and Campus Sustainability 
Assessment Framework (CSAF) (Maragakis \& Dobbelsteen, 2015). These initiatives show willingness of institutions to become more sustainable, while also providing them with 'sustainability' marketing materials.

As institutions continue their sustainability efforts, there is evidence that suggests that sustainability in higher education is missing a key component sought by students. Maragakis and Dobbelsteen (2013) conducted a survey of sustainability assessment systems within higher education that provided empirical data that identified a gap in current assessment methodologies. The study showed that 92 percent of participants agreed that employability after graduation should be included as a measure of sustainability while the most prominent external assessments currently do not address this aspect (Maragakis \& Dobbelsteen, 2013).

The unequivocal concern of students is not a new discovery as other research also supports these numbers (Becker, 1964; Anchor, Fiserova, Mariskova \& Urbanek, 2011; WU, 2011; Menon, Pashourtidou, Polycarpou \& Pashardes, 2012). It is, however, a fairly novel concept with regards to being identified as a metric for sustainability. This paper looks to review the existing literature regarding the economic returns of higher education and highlight gaps between students' expectations and reality.

\section{Methodology}

This research focuses on a literature review assessing relevant economic parameters associated with higher education attainment. The literature available on the economic return of degrees is sizeable and has been well studied over the last decades. The scope of this research is to identify useable information that can be used within the current identified needs and perceptions of sustainability in higher education.

The research presented applies to all forms of higher education, both academic and applied science. The research looks to provide an international view of the subject that specifically addresses trends and realities within higher education after 2010.

One aspect that will not be reviewed in depth is the difference between science, technology, engineering or math (STEM) and non-technical (social science) degrees. The subject of STEM versus social degrees is a very relative topic and one being addressed by governments internationally, such the Ethiopian Ministry of Education's 2008 policy whereby $70 \%$ of overall university enrolment is expected to be in a science field, with the remaining $30 \%$ in the social sciences (Egne, 2014). Although a very relative topic, these differences are not seen as being the root cause of capturing metrics and, as such, are not part of the scope of this study. This study looks to focus on the underlying expectations associated with the financial incentives of a degree. It is assumed that the correct metrics will be robust and flexible enough that they can be universally used and would automatically adjust for different types of degrees.

\section{Research Questions}

The research question underlying the study presented is: Should employability be considered as a parameter of sustainability assessments within higher education?

Outcome of this question will help to answer the main question: Can a set of factors be extrapolated to help guide the creation of a future metric for sustainability assessment of higher education? 


\section{Approach}

A broad ranging literature review was conducted in order to explore the gaps between students' financial expectations and post graduate metrics. Based on the results of the literature review, the author's expert judgment was used to extract key information from peer reviewed research and used them to propose several new economic metrics for consideration.

In order to discuss this topic with relation to sustainability in higher education, it is first important to baseline the meaning of the term 'sustainable'. The term sustainability is a highly debated word that still remains to be unanimously defined. However, the word sustainable is a more readily accepted word. Based on the World Commission on Environment and Development (1987) definition of 'sustainable development', a development that meets the needs of the present without compromising the needs of future generations, it means to be able to establish and maintain a balance between ecological and economic values, and equity across regions of the world. As Elkington (1997) proposed, the term can be divided into ecological, social and economic factors. Since Elkington, the first two factors have been investigated more extensively than the economic aspect of sustainability within higher education assessments.

To this extent, this research topic is novel and there are limited peer-reviewed studies that directly lend themselves to the sustainability aspects of economics of higher education. Thus, for this research to provide results, it will need to tie in various tangential fields associated with higher education. These include both government and academic lead research and, in some cases, well documented public responses.

Based on this approach there is the potential for promoting bias. This may stem from the amalgamation of various fields and there is a risk of inadvertently combining the literature in a way to support a specific belief. Although this bias cannot be measured this research aims to limit it by including various authors from other fields. It is expected that the varying views of authors and the necessary consensus required to achieve results will help limit any potential bias.

\section{Literature Selection}

It should be noted that the general topic of economic returns from higher education has been studied empirically and theoretically since the 1960s and has, arguably, produced tens of thousands of publications that could directly or indirectly support this paper. In order to encompass the most recent trends on this subject, literature selection was limited to peer-reviewed literature conducted post 2010. Literature selection was drawn from international sources to maintain the studies breadth and comprehensiveness. The literature identified to be presented reflects relevant literature that helps provide specific insight as to how to tie in economic parameters into sustainability assessments in higher education. 


\section{Review of Literature}

\section{Tuition fee}

As a general starting point, there is a plethora of public exposure regarding the cost of higher education. Tuition costs are an often-debated topic internationally. From the tuition fees hike riots in the UK (Cammaerts, 2013) to the 'skyrocketing' tuition costs in America (State of the Union Address, 2012) higher education is a focal point in media and public policy.

Tuition is a discrete figure that is often the starting point of assessing a higher education institution, but it is also not appropriate as a universal measure of comparison. Tuition is a result of an institutions pricing relative to the economic environment. Economic drivers such as location, the country's Gross Domestic Product (GDP), median salary, inflation, etc. help shape tuition numbers. Affordability is a term often used to normalize tuition relative to these economic parameters. Countries run their own statistic relative to higher education affordability, which helps guide policy. On a global level, affordability comparison is offered through various venues such as Education Policy Institute, which focuses on providing educational opportunities for all students, and the Higher Education Strategy Associates, which provide higher education decision makers with various metrics and strategic services.

As can be seen through various studies and national strategies, the price of tuition is often a barometer of social health and inclusiveness. Research spans the higher education lifecycle from secondary school through graduation. Cowan (2011) showed that a decrease in tuition also decreases risky health behaviours in youths as it increases their drive for a better future through higher education. Hübner (2012) looked at state-wide differences in Germany and found that a $€ 1000$ increase in tuition fees reduced enrolment by 2.7 percent. Hemelt \& Marcotte (2011) looked at 4-year public universities in the US and found a $\$ 1000$ decrease in tuition increased enrolment by about 2.5 percent. In the US, student debt greatly influences the graduation likelihood of students from the bottom 75 percent of the income distribution (Dwyer, McCloud \& Hodson, 2012), while in Ireland, tuition was abolished during the mid-nineties hoping to increase participation from students in low socio-economic status (Denny, 2014).

As research continues internationally, it is unclear if tuition levels are indeed a barrier limiting social equality. This is because there is an underlying expectation that higher education is an investment that will increase a graduate's future wages. Various studies have generalized higher education attainment as a financially lucrative proposition (Walker \& Zhu, 2011; Anchor et al., 2011 and others). Seeing education as an investment means that tuition may not act as a barrier if the returns outweigh the investment. But not all degrees are equal in providing a return on investment.

\section{Employability}

There is no doubt that the expansion of higher education has contributed fundamentally to the transformation of society through the development of human competencies (Organisation for Economic Cooperation and Development [OECD], 2011). However, human competencies are not necessarily synonymous with financial gains. Although this has been proposed since the 1960s (Becker, 1964) there is growing literature on the economic outcomes of different degrees. For example, there seems to be international 
convergence that social sciences are less favourable for employment (Menon et al., 2012; Schomburg \& Teichler, 2011). Tangentially, there is a growing sentiment amongst graduates and post-graduates that a Bachelor's degree is not enough (Schomburg \& Teichler, 2011).

Social science degrees, for example, often articulate a 'pie-in-the-sky' proposition that while low initial salaries are to be expected after graduation, the skills students have acquired in undergraduate studies (e.g. critical thinking) will be highly valued by employers over time and result in higher salaries later on during their career (Rajecki \& Borden, 2011). However, after investigating salaries across 120 different undergraduate majors, Rajecki and Borden concluded that mid-career salaries are highly correlated with starting salaries, and that the salaries earned by those who completed a degree in social sciences are below average compared to other fields. Therefore, this 'pie-in-thesky' proposal that value may be seen later may not be an accurate depiction of what future degree holders may expect to experience. It also leads to further discussion as to the importance of employability after graduation.

Although the definition of employability for graduates remains unclear it still persists to be a major motivation for students. The Bologne process in Europe, which aimed to create comparable, compatible and coherent systems of higher education in Europe (European Higher Education Area, 2014) also increases the mobility of high-level skills and labour and contribute to increased employment, productivity and growth (House of Commons Education and Skills Committee, 2007). With regards to students, Maragakis and Dobbelsteen (2013) found 92 percent students agree that employability should be included as a sustainability metric for higher education. This corresponds to academics also calling for employment to be a measure of sustainability (Ashford, Hall \& R Ashford, 2012).

Increasing the complexity of measuring employability of graduates are the realities of 'underemployment' and 'overeducation'. Underemployment is defined as those working part-time due to lack of full-time jobs, or those working part-time who would like to work more hours (Bell \& Blanchflower, 2011). Underemployment has been a growing concern since the financial crisis of 2008 and remains persistent (Ashford et al., 2012).

Simultaneously, overeducation has been a growing phenomenon in the modern job market. Overeducation is defined as someone whose respective levels of education exceed the requisite levels needed to perform their jobs (Linsley, 2005). The research by Carroll and Tani (2013) points to the growing concern surrounding over education in Australia and throughout the world.

\section{Financial Return}

The literature review sheds light on the complexities surrounding the financial parameters surrounding higher education attainment. The commitment required to obtain a higher education degree will always involve some sort of cost to the student, whether it involves time, money and/or a combination of the two.

The literature review generally covers topics that, for the most part, are widely discussed both socially and academically. Tuition prices, financial and social returns of higher education are prevalent in every layer of modern society. However, there seems to be some contradictory information with regard to the economic returns of higher education. 
There seems to be stark contradiction in assessing the financial returns of higher education. There are ample sources such as Walker and Zhu (2011), Anchor et al. (2011) and others which show that higher education will lead to greater financial returns. Although the framework of the research is sound, the generalization of the results needs to be questioned. It is clear that the economic returns of a social science are not equal to that of STEM degrees. And even within the STEM degrees there are differences in economic returns depending on the path selected and the educational attainment (Schomburg \& Teichler, 2011).

These studies also have not taken into account the modern reality of underemployment and overeducation. Now more than ever it is important for students to understand their opportunities and economic returns after graduation in order to make correct life decisions. It can be inferred that the economic burden of higher education may outweigh the employment returns based on the level of employability of a graduate.

\section{Discussion of the Literature Review with Relation to Sustainability in Higher Education}

The literature does not present discrete tools that would allow for financial assessment of higher education within the context of sustainability assessments. In order to make a more accurate forecast of the economic returns of a higher education degree one needs to understand both the inputs and the outputs of the degree.

The inputs for students to make a decision are readily available. A basic calculation utilizing the tuition, duration and miscellaneous costs can easily be obtained to create a realistic projection of the cost of the degree.

The financial outputs of the educational attainment are nebulous at best. Peer reviewed studies exist arguing the general positive economic returns of higher education (Walker \& Zhu, 2011; Anchor et al., 2011) while others indicate the inaccuracy of these claims (Rajecki \& Borden, 2011; Menon et al., 2012; Schomburg \& Teichler, 2011). A proxy to financial return may be the employability of a graduate, but this is far from being a discrete metric considering the complication of measuring underemployment or over education. Not knowing the expected return for an investment, or not being able to correctly forecast it, puts the student in an inopportune framework for making decisions. With regards to how sustainable higher education is, the literature review reveals a clear disconnect between student expectations and results.

These disconnects in the literature shows how students can get themselves into a financial unsustainable situation. Not knowing the returns of a higher education investment may lead to an unsustainable financial burden that may actually worsen an individual's standing. These results also coincide with American student loans which are currently skyrocketing and are unsustainable (State of the Union Address, 2012).

\section{Translation to Metrics for Sustainability Assessment}

Based on the research above several key pieces of work have been extrapolated and made into self-containing questions. These questions look to provide a framework for integrating discrete economic metrics regarding with regards to the sustainability of a higher education degree. 
Question 1: What is the average yearly salary of graduates with that specific degree within 12 months of graduation?

This question stems from the strong correlation that Rajecki and Borden (2011) identified between mid-career salaries and starting salaries. Rajecki and Borden (2011) also noted a notable difference between fields of studies so the question asks for the results of that specific degree to allow direct student comparison. A 12-month window is allowed so as to capture a suitable period of time after graduation.

Question 2: What is the ratio of full time / part time employed graduates with that specific degree within 12 months of graduation?

Underemployment is defined as those working part-time due to lack of full-time jobs, or those working part-time who would like to work more hours (Bell \& Blanchflower, 2011). Since underemployment has been a growing concern since the financial crisis of 2008 and remains persistent (Ashford et al., 2012) this question looks to provide students with a more meaningful number than just 'employability'. A 12-month window is allowed so as to capture a suitable period of time after graduation.

Question 3: What percent of graduates with that specific degree are employed in a position whose level of education exceeds the requisite levels needed to perform their job?

The research by Carroll and Tani (2013) points to the growing concern surrounding over education and this question uses Linsley (2005) definition to capture the level of over education experienced by a graduate of a specific degree within the market place.

\section{Conclusions and Discussions}

\section{Interpretation of Results}

From its inception, the OECD has stressed the importance of human competencies for economic and social development (2011). This, in general, can be translated as a growth of an individual in a personal and/or professional context. This guidance could also be inferred to as general guidance for sustainability assessments in higher education.

Thus for a degree to be assessed as sustainable in the economic context there needs to be at least two discrete elements presented to students for their economic decision making. The first is the cost of the education. This is a relatively straightforward calculation in which the parameters are readily available (tuition, opportunity costs, etc.).

The second element is the financial return of investment from the degree. This element presents the students with the varying monetary returns from different types of degrees and institutions. This would allow the student to decide on which institution to enrol in and the type of degree they would like to pursue based on their needs to develop their personal competencies. This should also be incorporated in sustainability assessments of higher education institutions.

The concepts presented in this paper are not new. In fact, the economic returns of degrees have been well studied in both an empirical and theoretical framework since the 1960's. However well studied these concepts are it is interesting that they still remain out of sustainability assessment of higher education institutions. Sustainability assessment, it seems, have actively avoided this topic as they focus on an academic institutions ability to develop human competencies, knowledge and innovation. However, as Ilisko \& Badoyanova (2014) highlighted, many heads of schools stated that "Schools should prepare the student for the requirements of a job market and to encourage them to live with a responsibility in everyday situations and in harmony with the environment." 
Makrakis \& Makrakis (2012) data showed that when addressing Sterling (2001) four-type typology of the roles and function if university (between socialization, liberal, vocational and transformative) $21 \%$ of students placed a focus on vocational training while $42 \%$ place an emphasis on the transformative function, which sees a university as an agent of change towards a fairer society and a better world. Considering the growing student debt burden, the university is not acting as an agent of change towards a fairer society. Including economic metrics would not only directly address the expectations of $21 \%$ of students that supported vocational training but also would support the transformative function by securing an economically sustainable graduate.

Based on the literature presented in this paper, it seems that sustainability assessments not including economic returns are missing a key parameter that may be contributing to the current unbalanced system.

\section{Discussion of Method Used for Comparison}

The research presented spans multiple fields in an attempt to capture a holistic review of current academic thought on the economic parameters surrounding the decision making of students that could be applied to sustainability assessments. The review covered qualitative and quantitative research and, in many cases, found potential contradictions, which made comparison of the research challenging. These challenges provide two valuable insights that may benefit future research.

The first insight is that apparent contradictions mainly stem from different point of views. For example, a broad analysis of higher education attainment may indeed find an increased rate of return while a more focused study may reveal a positive return for STEM fields and a negative return for social sciences. This means that the data needs to be carefully reviewed as it is not necessarily contradictory but rather biased towards a specific point of view. This makes the application into a sustainability assessment even more difficult as there will need to be some assumptions made by the assessment which may not necessarily achieve the desired results.

The other insight is that there is not yet a complete research surrounding the economic lifecycle of modern higher education. There is a general framework of understanding the inputs that go into accomplishing a degree, but the outputs are not discretely understood so as to provide guidance for sustainability assessments. Even some general metrics of post-graduate metrics may be incomplete or obsolete due to the changing market place and the drivers of employment that continuously affect the return of investment of a degree.

The research is subject to weakness as the amalgamation of all these topics can create distortion of facts. The economic inputs and outputs of higher education has produced a wealth of knowledge over the last several decades and the proper guidance needed for sustainability assessments may not be identified without the engagement of subject matter experts. Interpretations may lead to false assumptions which would increase omissions and limit critical review.

This weakness also led this research to set a very prescriptive description within the questions. Each question specified the results based upon the specific degree. This level of granularity is lacking from this literature reviewed but provides a clear assumption that aims to students making decisions as to which higher education path to follow. 


\section{Recommendations}

This study has highlighted the importance of understanding the economic returns of higher education within the framework of sustainability assessment. A degree should not be marketed as sustainable unless it addresses the economic return of the future graduate. In order to do this, further research should be undertaken to address some general parameters to help students in decision making.

One of the critical pieces of this research was to propose a framework for assessing an institutions ability to provide a degree that is economically sustainable within the framework of current student demands and sustainability assessments. This is a novel discussion in the context of sustainability assessments of higher education institutions, although not so novel in the general discussion of economic returns from higher education.

The research identified that economic returns must be more granular than just the institution; the metrics need to address the performance of the specific degree within the institution in order to provide a clear message to the students. This level of granulator would provide a robust method for assessing cross institutional performance of similar degrees.

With this in mind, further research needs to identify what are the most appropriate aspects to be measured as an economic output of a higher education degree within sustainability assessments. Traditional models that address rate of employability after graduation are not comprehensive enough. A framework should be researched that is robust and flexible enough to help students both now and in the future while keeping in mind that this is applying to the assessment of sustainability of an institution.

\section{References}

Anchor, J., Fiserova, J., Marsikova, K., \& Urbanek, V. (2011). Student expectations of the financial returns to higher education in the Czech Republic and England: Evidence from business schools. Economics of Education Review, 30, 673-681.

Ashford, N. A., Hall, R. P., \& Ashford, R. (2012). Addressing the crisis in employment and consumer demand: Reconciliation with financial and environmental sustainability. The European Financial Review, October-November, 2012, 63-68.

Becker, G. S. (1964). Human capital, a theoretical and empirical analysis with special reference to education. Chicago: Chicago University Press.

Bell, D. N. F. \& Blanchflower, D. G. (2011). Youth underemployment in the UK in the great recession. National Institute Economic Review, 215.

Bone, E., \& Agombar, J. (2011). First-year attitudes towards, and skills in, sustainable development. UK: University of Bath, The Higher Education Academy.

Cammaerts, B. (2013). The mediation of insurrectionary symbolic damage: The 2010 U.K. Student Protests. The International Journal of Press/Politics, 18 (4), 525-548.

Carroll, D. \& Tani, M. (2013). Over-education of recent higher education graduates: New Australian panel evidence. Economics of Education Review, 32, 207-218.

Comm, C. J. \& Mathaisel, D. F. X. (2003). Less is more: a framework for a sustainable university. International Journal of Sustainability in Higher Education, 4 (4), 314 323.

Connolly, T., Arkes, H. R., \& Hammond, K. R. (2000). Judgment and decision making: an interdisciplinary reader. Cambridge: Cambridge University Press. 
Cortese, A. D. (2003). The critical role of higher education in creating a sustainable future. Planning for Higher Education, March-May, 15-22.

Cowan, B. W. (2011). Forward-thinking teens: The effects of college costs on adolescent risky behavior. Economics of Education Review, 30, 813-825.

Datal-Clayton, B., \& Bass, S. (2002). Sustainable development strategies. London: Earth scan Publications Ltd.

Denny, K. (2013). The effect of abolishing university tuition costs: Evidence from Ireland. Labour Economics, 26, 26-33.

Dwyer, R.E., McCLoud, L. \& Hodson, R. (2012). Debt and graduation from American Universities. Social Forces, 90, 1133-1155.

Egne, R. M. (2014) Gender equality in public higher education institutions of Ethiopia: The case of science, technology, engineering, and mathematics. Discourse and Communication for Sustainable Education, 5, 3-21.

Elkington, J. (1997). Cannibals with forks: The triple bottom line of 21st century business. Oxford: Capstone Publishing.

European Higher Education Area (2014) Bologna Process - European Higher Education Area. Retrieved May 1, 2015, from http://www.ehea.info/

Greener, U. (2010). Higher education sustainability ratings, rankings and reviews (A Greener Guide). Retrieved May 3, 2015 from: http://www.greeneru.com/

Hemelt, S. W., \& Marcotte, D. E. (2011). The impact of tuition increases on enrolment at public colleges and universities. Educational Evaluation and Policy Analysis, 33 (4), 435-457.

Hemsley-Brown, J., \& Oplatka, I. (2006). Universities in a competitive global marketplace: A systematic review of the literature on higher education marketing. International Journal of Public Sector Management, 19, 316-338.

House of Commons Education and Skills Committee. (2007). The Bologna Process: Government Response to the Committee's Fourth Report of Session 2006-2007. London: The Stationery Office Limited.

Hübner, M. (2012). Do tuition fees affect enrolment behaviour? Evidence from a 'natural experiment' in Germany. Economics of Education Review, 31(6), 949-960.

Iliško, Dz. \& Badayanova, J. (2014). A case study of ESD implementation: Signs of sustainable leadership. Discourse and Communication for Sustainable Education, $5,38-48$.

Jucker, R. (2002). "Sustainability? Never heard of it!" Some basics we shouldn't ignore when engaging in education for sustainability. International Journal of Sustainability in Higher Education, 3(1), 8-18.

Kates, R. W., Clark, W. C., Corell R., Hall, J. M., Jaeger, C. C., Lowe, J. J., Dickinson, N. M. (2001). Sustainability science. Science, 292, 641-642.

Linsley, I. (2005). Causes of overeducation in the Australian labour market. Australian Journal of Labour Economics, 8(2), 121-143.

Makrakis, N. K. \& Makrakis, V. (2012) Processes, strategies and practices for turning the University of Crete into a Sustainable University. Discourse and Communication for Sustainable Education, 3, 5-22.

Maragakis, A., \& Dobbelsteen, A. (2013). Higher education: Features, trends and needs in relation to sustainability. Journal of Sustainability Education, 4, 1-20.

Maragakis, A., \& Dobbelsteen, A. (2015) Sustainability in higher education analysis and selection of assessment systems, Journal of Sustainable Development, 8 (3). 
McIntosh, M., Gaalswyk, K., Keniry, L., \& Eagan, D. (2008). Campus Environment 2008 - A National Report Card on Sustainability in Higher Education. National Wildlife Federation.

Menon, M.E., Pashourtidou, N., Polycarpou, A. \& Pashardes, P. (2012). Students' expectations about earnings and employment and the experience of recent university graduates: Evidence from Cyprus. International Journal of Educational Development, 32, 805-813.

Organisation for Economic Cooperation and Development. (2011). Education at a Glance 2011: OECD Indicators. OECD Publishing. DOI: 10.1787/eag-2011-en

Patrick, D. L., Murray, T., \& Bowles, I. A. (2008). Campus sustainability best practices. Massachusetts Executive Office of Energy and Environmental Affairs. Retrieved May 1, 2015, from: http://www.mass.gov/eea/docs/eea/lbe/lbe-campus-sustainpractices.pdf

Perna, T., Carriere, J., \& Chang, J. (2006). Sustainability governance: Evaluating policy development and implementation structures at the University of Toronto (Project for Env. 427). University of Toronto. Retrieved April 2, 2015, from: http://www. environment.utoronto.ca/upload/undergraduateresearchreports/421governance group06-07.pdf

Puukka, J. (2008). Mobilising higher education for sustainable development - lessons learnt from the OECD study. Proceedings of the 4th International Barcelona Conference on Higher Education, 7.

Rajecki, D., \& Borden, V. M. (2011). Psychology degrees: Employment, wage, and career trajectory consequences. Perspectives on Psychological Science, 6, 321-335.

Reid, A., \& Petocz, P. (2006). University lecturers' understanding of sustainability. Higher Education, 51, 105-123.

Ryan, A., Tilbury, D., Corcoran, P. B., Abe, O., \& Nomura, K. (2010). Sustainability in higher education in the Asia-Pacific: developments, challenges, and prospects. International Journal of Sustainability in Higher Education, 11, 106-119.

Saadatian, O., Dola, K. B., \& Tahir, O. M. (2011). Identifying strengths and weakness of sustainable higher educational assessment approaches. International Journal of Business and Social Science, 2(3), 137-146.

Salite,I. (2008). Educational action research for sustainability: Constructing a vision for the future teacher education. Journal of Teacher Education for Sustainability, $10,5-16$.

Schomburg, H., \& Teichlet, U. (2011). Employability and mobility of bachelor graduates in Europe. Key results of the Bologna process. Rotterdam: Sense Publishers.

Selby, D., Jones, P., \& Kagawa, F. (2009). Sustainability promotion and branding: Messaging challenges and possibilities for higher education institutions. Sustainability, 1, 537-555.

Sherman, D. (2008). Sustainability: What's the big idea? A strategy for transforming the higher education curriculum. Sustainability, 1(3), 188-195.

Shriberg, M. (2002). Institutional assessment tools for sustainability in higher education: strengths, weaknesses, and implications for practice and theory. Higher Education Policy, 15(2),153-167.

State of the Union Address, The. (2012). Retrieved April 6, 2015 from: http://www.white house.gov/the-press-office/2013/02/12/remarks-president-state-union-address 
Stephens, J. C. \& Graham, A. C. (2008). Exploring change towards sustainability in Universities by adapting transition management. Environmental Management of Sustainable Universities (EMSU) 2008 Conference: Barcelona.

Sterling, S. (2001). Sustainable education ń re-visioning learning and change. Schumacher Society Briefing, 6, Dartington: Schumacher Society, Green Books.

The Princeton Review. (2011). The Princeton review's guide to 311 Green Colleges. The Princeton Review. Retrieved May 5, 2015, from: http://www.centerforgreens chools.org/docs/Guideto311GreenColleges.pdf

TSL Education Ltd. (2012). World university rankings 2012-2013. Retrieved May 7, 2015, from: http://www.timeshighereducation.co.uk/world-university-rankings/ 2012-13/world-ranking

Walker, I., \& Zhu, Y. (2011). Differences by degree: Evidence of the net financial rates of return to undergraduate study for England and Wales. Economics of Education Review, 30, 1177-1186.

World Commission on Environment and Development. (1987). Our common future. Oxford: Oxford University Press.

Wu, C., (2011). High graduate unemployment rate and Taiwanese undergraduate education. International Journal of Educational Development, 31, 303-310.

Correspondence regarding this paper should be addressed to: Antonios Maragakis, Antonios Maragakis, Delft University of Technology, Faculty of Architecture and the Built Environment, Department of Architectural Engineering + Technology, P.O. Box 5043, 2600 GA Delft, The Netherlands, antonios.maragakis@gmail.com. 